\title{
Private Governance, Hegemonic Struggles, and Institutional Outcomes in the Transnational Cotton Commodity Chain
}

\author{
Amy Quark ${ }^{1}$ \\ The College of William and Mary \\ aaquark@wm.edu
}

\begin{abstract}
Transnational firms have rolled out new forms of private governance at the same time as the rise of new economic powerhouses like China has fomented growing inter-state tensions. This points to critical questions: how does inter-state competition shape private governance of transnational commodity chains and how does private governance shape inter-state rivalries? I explore these questions by tracing the construction and dissolution of sectoral hegemonic coalitions that govern commodity chains. Drawing on the case of cotton quality governance from 2000-2012, I argue that a coalition of the U.S. state and transnational merchants has reconstituted its sectoral hegemony to allow expanded accumulation and accommodate their main rival-China. The U.S. state created standards with Chinese characteristics, while transnational merchants made the authority structure of their institutions more inclusive. However, this reconstituted hegemony remains unstable. Facing continued regulatory competition from China, the U.S. state has constructed new forms of meta-governance that could facilitate a shift to Chinese-led sectoral hegemony but under U.S. oversight. Moreover, these sectoral hegemonic struggles compelled Western transnational merchants to fracture their long-standing relationship with the U.S. state in the hegemonic coalition in order to position their private institutions as geopolitically neutral and thus compatible with the hegemonic leadership of either the U.S. or Chinese states in the sector. By tracing struggles among coalitions of leading firms and states for hegemony over the institutions governing particular commodity chain sectors, we can shed light on possible trajectories within broader world-system level hegemonic struggles that at once constitute and are constituted by these sectoral dynamics.
\end{abstract}

Keywords: Commodity chain, hegemony, hegemonic rivalry, private governance, China

\footnotetext{
${ }^{1}$ Acknowledgements: The author thanks Jenn Bair, Tim Bartley, Brent Kaup, Nitsan Chorev, and three anonymous reviewers for comments on this manuscript. An earlier draft of this manuscript was presented at the 2013 Annual Meetings of the American Sociological Association. This research was generously funded by fellowships from the Social Sciences and Humanities Research Council of Canada and the Canadian Federation of University Women.
} 


\section{Journal of World-Systems Research}

Recent scholarship points to two major transformations in the governance of the global economy. On one hand, scholars emphasize the growing role of transnational corporations in constructing private institutions to govern transnational commodity chains (Bartley 2007; Cutler 2002, 2003; Cutler et al. 1999; Dicken 2003; Dolan and Humphrey 2000; Gereffi 1994, 1999; Haufler 2001, 2003). On the other hand, scholars claim that the emergence of economic powerhouses such as China and the deterioration of U.S. hegemony signal a period of hegemonic struggle (Beeson 2013; Gills 2010; Pieterse 2011; Review of International Political Economy 2013; Third World Quarterly 2013a,b; Vanaik 2013). While much scholarly attention has been devoted to each of these phenomena, less attention has been given to their intersection. This raises critical questions. How does inter-state competition shape private governance of transnational commodity chains? How does private governance shape inter-state rivalries?

The original conceptualization of the commodity chain in world-systems analysis was designed to capture the intersection of these two phenomena. Hopkins and Wallerstein introduced the commodity chain to analyze how transnational production and inter-state competition intersect in the (re)creation of the dynamic, hierarchical world-economy. However, the bulk of the recent work on commodity chains, and particularly the influential work of Gary Gereffi (e.g. 1994, 1999; Bair and Gereffi 2001; Gereffi et al. 2005), has departed significantly from these concerns. In this paper, I follow Bair's (2005) call to return to the roots of commodity chain research in world-systems analysis. I link the study of commodity chains to the broader dynamics of hegemonic struggle and transition as outlined in the work of Giovanni Arrighi and his colleagues (e.g. Arrighi 1994, 2007; Arrighi and Silver 1999). In doing so, I argue that the intersection of private governance and inter-state rivalries can best be understood by tracing the construction and dissolution of sectoral hegemonic coalitions. By tracing struggles among coalitions of leading firms and states for hegemony over the institutions governing particular commodity chain sectors, we can shed light on the trajectories of sectoral level governance which are constituted by and constitutive of broader world-system level hegemonic struggles.

Empirically, I explore these ideas through the case of quality governance in the transnational cotton trade from 2000-2012. In the early $20^{\text {th }}$ century, a coalition of the U.S. state and Western transnational merchants established hegemonic state and private institutions to govern quality and dispute settlement for the sale of U.S. cotton abroad. These hegemonic institutions, however, came to be challenged in the early $2000 \mathrm{~s}$. At this time, the U.S. state and U.S. cotton producers claimed a 40 percent market share of the global import market for cotton, and a handful of the largest Western transnational merchants, who linked buyers and sellers around the world, likely controlled 45 percent of all transnationally traded cotton. However, the liberalization of the apparel and textile trade through the WTO made China the largest producer of textiles and apparel - and the largest importer of cotton — in the world, with a 35-40 percent market share of cotton imports. With this new market power and distinct preferences vis-à-vis quality governance, textile manufacturers in China and the Chinese state challenged the state and private institutions of the U.S. coalition, destabilizing their hegemony.

Through an analysis of this struggle over cotton quality governance, I argue that the U.S.led coalition has reconstituted its sectoral hegemony by retooling its institutions to both expand accumulation and accommodate its main rival - China. The U.S. state created standards with Chinese characteristics, while transnational merchants made the authority structure of their private institutions more inclusive to increase Chinese membership. However, this reconstituted hegemony remains unstable. Facing continued regulatory competition from China, the U.S. state has constructed new forms of meta-governance that could facilitate a shift to Chinese-led 
sectoral hegemony but under U.S. oversight. Moreover, these hegemonic struggles compelled Western transnational merchants to fracture their long-standing relationship with the U.S. state in order to position their private institutions as geopolitically neutral and thus compatible with the hegemonic leadership of either the U.S. or Chinese states. Although this struggle is ongoing, these competitive institutional innovations have generated a new track along which subsequent struggles will unfold.

\section{Commodity Chains and Hegemonic Struggles}

One of the basic, orienting concerns of the world-systems approach is to understand the tension between inter-state competition and the organization of production on a world-scale. These phenomena are inherently contradictory, Hopkins and Wallerstein explain, as "the economy is primarily a 'world' structure, but political activity takes place primarily within and through statestructures whose boundaries are narrower than those of the economy" (1977:127). The concept of the commodity chain was introduced as a way to trace the effects of these contradictory tendencies on the organization of the capitalist world-economy. Hopkins and Wallerstein defined the commodity chain as "a network of labor and production processes whose end result is a finished commodity" (1986:159). Tracing the network of the commodity chain allows one to capture processes of accumulation that traverse state borders as part of the ongoing impulse towards economic integration. At the same time, through competition to capture the benefits of capital accumulation, states restructure the organization of production and thus the distribution of surplus value in the world-economy (Hopkins and Wallerstein 1977:120-22).

Although a vast literature on commodity chains exists, most of this work does not follow the world-systems approach and its guiding concerns, particularly in the study of contemporary commodity chains (for exceptions, see Ciccantell and Smith 2009; Quark 2008, 2013; Talbot 2004). ${ }^{2}$ Rather, much of this scholarship follows the work of Gary Gereffi on global commodity/value chains (GCC/GVC) (Gereffi 1994, 1999; Gereffi and Korzeniewicz 1994; Bair and Gereffi 2001; Gereffi et al. 2005). Emerging out of the world-systems tradition, Gereffi's (1994) early work offered a methodological approach for mapping spatially dispersed and organizationally complex production networks. A key contribution of this work was its focus on the role of transnational capital - and especially commercial capital - in the organization of production on a world-scale. His more recent work attempts to explain variance in the forms of coordination used across distinct value chains, focusing primarily on three sectoral-level variables: the complexity of transactions, the codifiability of information, and the capability of suppliers (Gereffi et al. 2005). Overall, while offering some key insights into the governance of contemporary commodity chains, Gereffi's evolving agenda narrowed the scope of research in comparison to the original guiding concerns of world-systems analysis. As Bair (2005:154) argues, Gereffi and his followers have focused on "the meso level of sectoral dynamics and/or the micro level of firm upgrading" while de-emphasizing "the larger institutional and structural environments in which commodity chains are embedded." Bair (2005) thus calls for a return to the broader orienting concerns of world-systems analysis.

To this end, I argue that there are gains to be made from linking the study of institutions governing individual commodity chains to the Gramscian-inspired work of Giovanni Arrighi and the dynamics of hegemonic struggle and transition that he traces (see also Talbot 2004). Arrighi

\footnotetext{
${ }^{2}$ For recent work on historical commodity chains guided by world-systems analysis, see Moore 2010; Review 2000; Tomich 1990.
} 


\section{Journal of World-Systems Research}

follows Gramsci (1971) in seeing the capitalist world-economy as an institutionalized social order ( $c f$. Wallerstein 1984). That is, the capitalist world-economy is (re)constructed through struggle and in large part through efforts by economic and political elites to instantiate their interests in the institutions that allow capitalism to operate. Arrighi (1994) argues that the worldsystem develops through periods of stable capital accumulation in which institutional power is held by a hegemonic coalition of state and business agencies. These periods of stable accumulation are followed by periods of crisis and "discontinuous change" in which rival coalitions compete to create new institutions that at once reorganize the world-economy on new and enlarged foundations and capture the lion's share of the benefits for the new hegemonic coalition (Arrighi 1994:1). According to Arrighi and Silver (2001:258), the crisis of overaccumulation that began in the $1970 \mathrm{~s}$ and the concomitant deterioration of U.S.-led hegemony signaled the beginning of a period of crisis characterized by "uncertainty and unpredictability" as actors compete to establish new institutions to govern the capitalist worldeconomy.

Arrighi's framework of systemic cycles of accumulation and hegemonic transition addresses shifts at the macro-scale. However, Gramsci (1971) understood power as diffuse; the hegemony of the ruling class is constructed through a web of institutions, social relations, and ideas operating through a plurality of sites of governance (Overbeek 2005). From this view, any macro-level hegemonic transition is constitutive of and constituted by struggles over myriad institutions governing the world-system, not least of which are the institutions governing commodity chains. As such, studying hegemonic struggles within particular sectors can help trace the contours of a broader (possible) hegemonic transition, which is as yet unclear. Arrighi insists that the current "crisis has more than one possible solution, and which particular solution will eventually materialize depends on an on-going process of struggle" (2005:67). Although potentially ascendant hegemons like China exist, Hung sees "a cacophony of possible trajectories of global change" (2009:17).

To be sure, we see crisis dynamics destabilizing existing governance institutions in contemporary commodity chains. Periods of hegemonic crisis, according to Arrighi, are characterized by three distinct processes: "the intensification of inter-state and inter-enterprise competition; the escalation of social conflicts; and the interstitial emergence of new configurations of power" (2005:63; see also Arrighi and Silver 1999). In the 2000s, and particularly after the financial crisis of 2008, firms in emerging economies backed by powerful states such as the BRICs (Brazil, Russia, India and China) have intensified competition with Western-led firms (Appelbaum 2009; Gereffi 2013). Along with intensifying inter-state and inter-firm competition, we see growing social conflict in the proliferation of efforts to reform the governance of commodity chains to address social and environmental concerns (Bartley 2007; Jaffee 2007; Seidman 2007), as well as broader challenges such as the World Social Forum and Occupy Wall Street.

What is of particular interest here is how the intensification of struggles within commodity chains are generating new configurations of power and new institutions to instantiate them. Arrighi (1994) argues that the instability and uncertainty created by periods of crisis are only solved when a leading complex of governmental and business agencies is able to establish hegemony. Arrighi (1994) follows Gramsci's (1971) definition of hegemony as rule by consent, backed only in the last instance by coercion. Institutions are central to the construction of hegemony. Complexes of governmental and business enterprises secure a hegemonic role by fostering new forms of inter-state and inter-firm cooperation within institutions to overcome "the 
tendency of the separate states [and firms] to pursue their national interest without regard for system-level problems that require system-level solutions" (Arrighi 2005:63).

These hegemonic functions can also be understood to exist on the sectoral level for the governance of commodity chains. While Gereffi's work focused on the governance role of transnational firms, I conceptualize the hegemonic coalition on a sectoral level as consisting of one or more states and lead firms that take the lead role in providing a constellation of state and private institutions which allows expanded accumulation in the sector-institutions such as quality standards and rules for contracts and dispute settlement. While much of the work on commodity chains has focused on the dominance of lead firms, I focus on the additional power accrued to lead actors - both firms and states - by achieving hegemony or consent to their rule.

Gramsci (1971) suggests that rival coalitions use two main strategies to develop the cooperation required for hegemony. First, they can provide material concessions to potential challengers. In sectoral institutions, elites provide material concessions primarily through the procedures their institutions use to make, apply and enforce rules (Chorev and Babb 2009). For example, as Chorev and Babb (2009) argue in their study of the World Trade Organization (WTO) and the International Monetary Fund (IMF), the resiliency of these different institutions of U.S. hegemony depends on whether their procedures encourage "exit" or "voice" among challengers. Second, rival coalitions can provide moral and intellectual leadership by claiming that the institutions privileging their interests also represent the collective interest (Arrighi 1994; Gramsci 1971). While this claim is always more or less fraudulent, following Gramsci (1971) and Arrighi (1994), hegemony only occurs when the claim is at least partially true - when the new institutions provide a collective benefit while also expanding the power of the dominant group.

\section{Challenges to Achieving Hegemony in Periods of Crisis}

From this view, we can conceptualize the institutions governing commodity chains as sites of hegemonic struggle. Both the existing hegemonic coalition and new rival coalitions can draw on these hegemony-building strategies. However, different actors face distinct challenges in their efforts to claim their position in the sectoral-level hegemonic coalition.

Since the postwar period, a range of agencies of the U.S. state has assumed a lead role in constructing the institutional foundations for expanded trade for a wide range of commodity chains. This has involved providing state regulation that creates a calculable environment in which transnational firms could expand and develop complementary private governance institutions. However, these U.S. state agencies now face several difficulties in their attempts to maintain their power during a period of hegemonic rivalry. First, emerging rival states seek to challenge or even supplant the leadership role of U.S. state agencies in order to privilege "their" firms and to capture greater benefits of global capital accumulation for their territory. Second, U.S. state agencies face difficulties balancing growing divergence among the domestic class fractions that form the core of their hegemonic coalition, particularly as transnational firms develop interests that do not align as easily with other, less mobile, domestic groups.

In addition to state agencies, periods of crisis also create new and distinct challenges for leading firms in the hegemonic coalition and can destabilize existing private governance institutions. In the current period of crisis, hegemonic rivalries are creating new challenges for Western transnational firms. First, their own governance roles within the hegemonic coalition are being challenged by geographically differentiated firms, and particularly increasingly powerful 


\section{Journal of World-Systems Research}

firms in China (e.g. Appelbaum 2009). Second, Western transnational firms are challenged by the declining ability of U.S. state agencies to deliver a stable institutional foundation for expanded accumulation, given the intensification of state rivalries. Historically, Western transnational firms have relied on U.S. state agencies to create and maintain the institutional foundations necessary for their transnational expansion and for the operation of their private governance arrangements. However, as the legitimacy of U.S. state agencies deteriorates, Western transnational firms risk either growing instability in a global trade without the necessary institutional foundations or the emergence of new institutions generated by a rival state that may privilege the interests of different firms.

This leads to the third, related challenge facing Western transnational firms: they must also secure consent to their rule from other states and particularly from emerging state rivals who seek a prime position in a new hegemonic coalition. While Western firms might prefer to see the hegemonic role of U.S. state agencies reproduced, they must also navigate the possibility that these U.S. state agencies may no longer be able to perform these functions and that they will need independently to ensure their own hegemonic position. These firms are dependent on state regulation to undergird their private governance, but to reproduce their private institutional power transnational firms may need to be flexible regarding which states provide the institutional foundations for their expanded accumulation.

Finally, while new rival complexes of states and firms may be gaining economic leverage, they also face difficulties in their efforts to challenge the sectoral governance institutions of the ruling hegemonic coalition. Perhaps most critically, they face the problem of institutional dependence. That is, rivals are reliant on the institutions of the declining hegemonic coalition even as they attempt to replace or reconstitute them to serve their interests. This mirrors earlier scholars' insights regarding technological and financial dependence in the global South (Cardoso and Faletto 1979; Smith 1993). As Steinfeld argues, the ability of Chinese firms and the Chinese state to change the rules of the game to better serve their interests is complicated by the fact that their economic and political power has grown within "a game created and defined by the world's advanced industrial economies, most notably the United States" (2010:24). Actors construct governance institutions to solve the problems they face given their historically and spatially-specific position within processes of accumulation. These institutions then carry with them complex and historically-specific constellations of knowledge/expertise, technology, materiality, discursive legitimations, social roles, and relationships that cannot be cast aside, transplanted elsewhere, or redirected to serve different interests in a simple and straightforward way.

\section{New Power Configurations and Novel Institutions}

As these different contenders for a position in the sectoral hegemonic coalition engage in hegemony-building strategies, their competitive efforts can generate new configurations of power and novel institutions that depart significantly from those characterizing the declining hegemonic coalition. As Arrighi and Silver (2001:261) describe for the world-system as a whole, emergent hegemonic coalitions act as "tracklaying vehicles" which lead the system in a new direction and, in doing so, transform it. "Far from proceeding along a single track...," they argue, "the formation and expansion of the world capitalist system has thus occurred through several switches to new tracks laid by specific complexes of governmental and business agencies" 
(Arrighi and Silver 2001:261). In this messy period of transition, we must assume that the nature of any emergent coalition is still in the process of formation. That said, we can evaluate the contours of an emergent coalition along six key axes:

1) The leading state apparatus: Arrighi (1994) traced the transformation of state apparatuses from the city-states of Italy to the trans-statal and inter-statal organizations that upheld U.S. hegemony. On a sectoral level, we can trace how state bodies transform and transnationalize their operations in efforts to construct their hegemony over sectoral governance functions. In the current period, any emergent leading state apparatus will necessarily be mediated by new and existing international organizations that can provide the institutional foundation for expanded accumulation.

2) The leading fraction of capital: Each coalition is led by a different fraction of capital, be it mercantile, industrial or financial capital, or, in Gereffi's (1994) terms, by firms at different nodes in the commodity chain. These lead firms construct private governance institutions that advance their interests, although the concessions required to construct consent to their rule can create some limits to the inequalities among different fractions of capital. In the current period, although Western transnational firms face new challengers, the growing transnational integration of capital through joint ventures and mergers suggests that any new coalition of lead firms is unlikely to simply supplant highly flexible and mobile Western capital.

3) The geographical centering: Each coalition is geographically-specific in that, by constructing their own institutional advantages, the coalition generates inequalities across geographic regions of the world-system. The concessions required to gain consent to one's rule, however, can dampen these geographic inequalities to a degree.

4) The state-capital nexus: This refers to the division of governance labor between state and capital. Van Apeldoorn et al. (2012:468) suggest that the state-capital nexus has undergone deep transformations in the history of capitalism "from the nexus between mercantile capital and the absolutist state in the seventeenth and eighteenth centuries to the liberal state and early industrial capital in the nineteenth century, to the nexus between late industrial capital and the emerging welfare state in the phases of monopoly capitalism and corporate liberalism in the first three quarters of the twentieth century, to finally the nexus between financial capital and the neoliberal state in the last four decades." We would thus expect a hegemonic transition to further reconstitute the statecapital nexus, particularly as novel state-capital relationships that depart significantly from the neoliberal model have powered the rise of many of the emerging economies (see Review of International Political Economy 2013).

5) The geographic reach of the institutions: As hegemony-building can involve creating new allies and persuading potential rivals to accept one's preferred institutions, these processes can transform the geographic reach or jurisdiction of the state and private institutions governing the sector.

6) Legitimating discourse: As each hegemony-building project involves crafting a discourse that can cast the narrow concerns of the leading firms and states as collective concerns of the sector as a whole, we would expect temporally, spatially and sectorspecific discourses to emerge that nonetheless draw on discourses circulating in the world-economy more generally. 
Table 1. The Transformation of Sectoral Hegemonies in the Transnational Cotton Trade

\begin{tabular}{|c|c|c|c|}
\hline & $\begin{array}{c}\text { U.S.-led Hegem ony, } \\
1923-2001\end{array}$ & $\begin{array}{l}\text { Reconstituted U.S.-led } \\
\text { Hegemony, 2002-? }\end{array}$ & $\begin{array}{l}\text { Threat from Chinese- } \\
\text { led Coalition, 2002-? }\end{array}$ \\
\hline State apparatus & $\begin{array}{l}\text { U.S. national state agency } \\
\text { (USDA) with advisory role } \\
\text { for buyers of U.S. cotton }\end{array}$ & $\begin{array}{l}\text { U.S. national state agency } \\
\text { operating through inter-state } \\
\text { organization representing } \\
\text { cotton buyers and sellers } \\
\text { (ICAC) and backed by } \\
\text { procedural standards } \\
\text { approved in international } \\
\text { standards developing } \\
\text { organizations }\end{array}$ & $\begin{array}{l}\text { Chinese national state } \\
\text { agency (strong threat) }\end{array}$ \\
\hline $\begin{array}{c}\text { Fraction of } \\
\text { capital }\end{array}$ & $\begin{array}{l}\text { Western transnational } \\
\text { merchants in national trade } \\
\text { associations }\end{array}$ & $\begin{array}{l}\text { Western transnational } \\
\text { merchants in transnational } \\
\text { trade association but with } \\
\text { increasing role of textile } \\
\text { manufacturers }\end{array}$ & $\begin{array}{l}\text { Textile manufacturers } \\
\text { in national trade } \\
\text { association (weak } \\
\text { threat) }\end{array}$ \\
\hline $\begin{array}{l}\text { Geographical } \\
\text { centering }\end{array}$ & U.S.-centered & $\begin{array}{l}\text { U.S.-centered but with } \\
\text { increasing Chinese } \\
\text { characteristics }\end{array}$ & Chinese-centered \\
\hline $\begin{array}{l}\text { State-capital } \\
\text { nexus }\end{array}$ & $\begin{array}{l}\text { State control of definition } \\
\text { of quality and benchmark } \\
\text { cottons } \\
\text { Private control of dispute } \\
\text { settlement }\end{array}$ & $\begin{array}{l}\text { State control of definition of } \\
\text { quality and benchmark } \\
\text { cottons } \\
\text { Private control of dispute } \\
\text { settlement }\end{array}$ & $\begin{array}{l}\text { State control of } \\
\text { definition of quality } \\
\text { and benchmark cottons } \\
\text { Private control of } \\
\text { dispute settlement with } \\
\text { role for the state in } \\
\text { verification of contract } \\
\text { terms }\end{array}$ \\
\hline $\begin{array}{l}\text { Geographic } \\
\text { reach }\end{array}$ & $\begin{array}{l}\text { Formal jurisdiction over } \\
\text { trade of U.S. cotton }\end{array}$ & $\begin{array}{l}\text { Formal jurisdiction over } \\
\text { trade of cotton generally } \\
\text { (although incomplete) }\end{array}$ & $\begin{array}{l}\text { Formal jurisdiction } \\
\text { over trade of cotton } \\
\text { into China }\end{array}$ \\
\hline $\begin{array}{l}\text { Legitimating } \\
\text { discourse }\end{array}$ & $\begin{array}{l}\text { Scientific validity } \\
\text { Liberal economic view of } \\
\text { contracts }\end{array}$ & $\begin{array}{l}\text { Scientific validity } \\
\text { Neoliberal business ethics }\end{array}$ & $\begin{array}{l}\text { An "alternative" for } \\
\text { the cotton trade }\end{array}$ \\
\hline
\end{tabular}

The remaining segments of the paper use these axes of analysis to examine the transformation of sectoral hegemonies over quality governance in the transnational cotton trade. The analysis is summarized in Table 1. Following a discussion of methodology, I introduce the institutional arrangements that were established in the early 1920 s to solidify U.S.-led hegemony and that would govern the cotton sector, largely unchanged, until the early $2000 \mathrm{~s}$. The characteristics of this sectoral hegemony are summarized in the second column of Table 1. After establishing this historical baseline, I explore the intense contestation that emerged as this U.S.led sectoral hegemony faced new challenges from an increasingly powerful Chinese-led coalition at the turn of the $21^{\text {st }}$ century. While this contestation has not been fully resolved, the third and fourth columns in Table 1 summarize the two key dynamics identified in this period. On one 
hand, given the threat from the Chinese-led coalition, the U.S.-led coalition has attempted to reconstitute its sectoral hegemony by offering concessions to incorporate its new rival. On the other hand, the Chinese-led coalition continues to pose a threat to the stability of this reconstituted hegemony.

\section{Methods}

This study is based on multi-sited structural fieldwork, using the commodity chain as a methodological tool to track actors that are at once linked in the global cotton trade and embedded in place-specific constellations of labor, technology, culture, and business practices (see Collins 2005; Gellert and Shefner 2009). I collected and analyzed three types of data using this approach: 1) primary documents including news articles, annual reports, meeting minutes, and policy documents; 2) statistics on changes in cotton production, consumption and trade globally from 1970 to the present from a dataset I obtained from the International Cotton Advisory Committee (ICAC); and, 3) qualitative data gathered via multi-sited research, including approximately 80 semi-structured interviews and observation at four international cotton industry conferences.

Following the commodity chain methodology, my sampling strategy for interviews aimed to capture variation both within different nodes of the commodity chain and across different geographic locations. To this end, I interviewed actors in each of the key nodes or positions within the cotton trade-cotton producers, transnational and local cotton merchants, and yarn/textile manufacturers - and/or officials from trade associations representing these actors. I also sought to maximize geographical diversity by interviewing actors during field visits to China, Benin, Brazil, Britain, and the United States, as well as during the cotton industry conferences I attended. As these actors involved directly in the trade are further embedded in webs of social relations, I also interviewed government officials, fiber scientists, and various firms that provide services to the cotton trade (i.e. inspection firms, shipping firms, insurance firms, etc.).

\section{The U.S.-led Sectoral Hegemony of the Transnational Cotton Trade}

The governance of cotton quality involves three key governance tasks: the definition of quality, or determining what characteristics of the cotton should be evaluated to determine its price and establish grades (categories used to implement the standards); the creation of benchmark cottons, or the highly manipulable process of making physical representations of the 'true' value of the different grades; and, the settlement of disputes. For much of the $20^{\text {th }}$ century, these governance tasks for the transnational trade in cotton were controlled by a U.S.-led hegemonic coalition. The institutional centerpiece of this sectoral hegemony was the Universal Cotton Standards Agreement. Established in 1923, this was an agreement between the U.S. government, representing U.S. cotton producers, merchants, and textile manufacturers, and foreign, private trade associations representing merchants and textile manufacturers in cotton-importing countries abroad, over who would govern quality standards for the transnational trade of U.S. cotton. Through this agreement, the USDA controlled two of the three quality governance tasks: the definition of quality and the creation of benchmark cottons. To gain consent to its institutional power, the USDA legitimated its standards through a discourse of scientism, or the belief that policy is best dictated by science (Tenny 1925). Moreover, the USDA gave material 


\section{Journal of World-Systems Research}

concessions, offering foreign, private trade associations, as well as representatives of U.S. cotton producers, merchants, and textile manufacturers, an advisory role, which involved voting on revisions to the definition of quality and inspecting the benchmark cottons (USDA 1924). The third quality governance task - the settlement of disputes - was delegated to private, nationallybased trade associations and legitimated through a liberal economic discourse that posited a limited role for the state (Tenny 1925; USDA 1924). Domestic and/or foreign merchants largely dominated these trade associations, the most prominent of which were the Liverpool Cotton Association in the U.K. and the American Cotton Shippers Association in the U.S. The private arbitral bodies of these trade associations would settle contract disputes by determining the quality of cotton through comparison to the USDA benchmark standards. These arbitration decisions were enforced through private mechanisms such as blacklists of recalcitrant parties. In addition, at least domestically, arbitration awards were enforceable in U.S. courts. These governance arrangements forged by the U.S.-led hegemonic coalition governed the cotton sector until a challenge from China emerged at the turn of the $21^{\text {st }}$ century.

\section{The WTO, China, and New Configurations of Power}

While tensions within the U.S. hegemonic coalition emerged in the $1970 \mathrm{~s}$, the formal establishment of the World Trade Organization (WTO) in 1995 was the critical turning point that intensified inter-state and inter-firm competition over quality governance. The WTO solidified the rise of China as a dominant player in the global cotton trade through the Agreement on Textiles and Clothing, which liberalized the long-protected apparel and textile trade between 1995 and 2005 (Rosen 2002). Paired with China's accession to the WTO in 2001, this trade liberalization made China the largest producer of textiles and apparel—and the largest importer of cotton - in the world. Chinese firms were able to radically increase their apparel exports, the value of which skyrocketed from $\$ 24$ billion in 1995 to $\$ 120$ billion in 2008 (Gereffi and Frederick 2010). Although China was the largest producer of cotton in the world, industrial cotton consumption outstripped domestic cotton production by 30\% from 2003-2008 (ICAC 2008). Thus, as the value of China's apparel exports increased, its share of world cotton imports also rose steeply from approximately 2 percent to 43 percent from 2001 to 2005 (ICAC 2008). China became the major player in the cotton import market as the next largest importers, Turkey and Indonesia, claimed just 8\% and 10\% market shares, respectively from 2003-2008 (ICAC 2008).

The establishment of the WTO, however, also reinforced U.S. cotton producers' position as dominant cotton exporters. The flip side of this tremendous growth in textile and apparel manufacturing in China was, of course, the continued decline of textile manufacturing in the United States and around the world. While U.S. textile manufacturers' use of cotton peaked in 1997, it fell by $70 \%$ by 2008 as demand for cotton shifted even more decidedly to Asia and to China (USDA 2011). The competition among exporters in this growing transnational trade was supposed to unfold in a liberalized agricultural market as states had agreed to reduce government intervention in agriculture through the 1995 Agreement on Agriculture (AoA) (McMichael 2004). In particular, the AoA threatened to undermine U.S. cotton producers' positions as major exporters. Analysts estimated that the removal of U.S. production and export subsidies in line with the AoA would reduce U.S. cotton production by 20 percent and U.S. exports by 50 percent, which would increase the international price of cotton in the short-term and shift production and export dominance to other countries in the longer term (Baffes et al. 2004). As 
such, powerful farm groups successfully lobbied to keep the U.S. government from implementing their AoA commitments. Thus, while U.S. cotton consumption decreased with the liberalization of the apparel and textile trade, U.S. cotton production and exports increased. As a result, the U.S. maintained its position as a dominant exporter with about a $39 \%$ percent share of world cotton exports from 2003-2008, compared to the market shares of about $10 \%$ claimed by its closest competitors (India and Uzbekistan) (ICAC 2008).

Finally, the expansion of production and trade following the end of the Multi-Fiber Arrangement (MFA) further solidified the role of transnational cotton merchants as middlemen in the global market. Large U.S. and European merchants had extended the transnational scope of their operation in the $1980 \mathrm{~s}$ and $1990 \mathrm{~s}$, particularly with the privatization of state trading enterprises in many countries through structural adjustment programs (Baffes 2001). These Western transnational merchants were well-positioned to take advantage of the post-MFA boom in transnationally traded cotton. While precise data on firm market share is difficult to obtain, some estimate that the ten largest companies handled more than two-thirds of the annual transnational cotton trade during the 2000s (Çalişkan 2010:61), and that by 2009 four firms controlled over half of the transnational trade (Carpenter 2009). In short, competition over the governance of the cotton trade shaped up to be a battle of giants.

\section{The Threat of Rival Quality Governance Institutions}

With the rise of China as a new rival, the U.S.-led coalition faced new challenges to its sectoral hegemony. A coalition of the Chinese state and textile manufacturers in China had different preferences for quality governance than the U.S.-led coalition (see, e.g. CSITC Task Force 2007:4; WTO 2002). Indeed, they saw the state and private governance institutions dominated by the U.S.-led coalition as privileging the interests of Western actors and their distinct factor endowments and technological choices. For example, from the perspective of textile manufacturers in China, the U.S.' quality classification system had been developed to meet the needs of U.S. and Western European textile manufacturers who used capital-intensive rotor spinning technology, and not those of textile manufacturers in China who used the more laborintensive ring spinning technology. Textile manufacturers using different technologies privileged different fiber characteristics - particularly fiber length vs. fiber strength — and thus had different interests in quality standards (Estur 2004; Perkins et al. 1984). As the U.S. system had been designed to reflect the interests of Western manufacturers, it did not measure additional fiber characteristics, such as short fiber content, or the ratio of short to long fibers in a sample, which would be particularly useful for ring spinning.

Similarly, textile manufacturers in China and the Chinese state viewed the transnational merchants' trade association, the Liverpool Cotton Association (LCA), as an institution instantiating U.S. and European interests and the interests of merchants over textile manufacturers in dispute settlement. While Western transnational merchants saw their trade association as the legitimate arbitral body for the settlement of contract disputes in the transnational trade, textile manufacturers in China preferred that disputes be arbitrated by the Chinese arbitral body, the China International Economic and Trade Arbitration Commission (CIETAC). Private arbitral bodies can vary significantly based on their historical development in relation to the domestic legal professions, practices, and legal systems of particular countries and/or sectors (Dezalay and Garth 1995). The LCA, for example, developed out of the AngloAmerican arbitration tradition and legal systems and was steeped in the private rules, norms, and 
culture of the merchant community. CIETAC, in contrast, was developed in relation to the legal rules and cultural norms in China. While Western ideas of contract law privileged freedom of contract, in China, state courts and legal norms remained highly embedded in guanxi, or networks of personal relations (Chung and Hamilton 2001).

Given their distinct preferences, textile manufacturers in China and the Chinese state aimed to challenge the USDA's authority over these three tasks of quality governance: the definition of quality, the creation of benchmark cottons, and the settlement of disputes (see, e.g. Fang 2009; CSTIC 2007; WTO 2002). In doing so, however, the Chinese state faced the problem of institutional dependence. The Chinese standards agency, the China Fiber Inspection Bureau (CFIB), had largely been using manual fiber evaluation as the basis for domestic quality governance (Keyes et al. 2005). In contrast, the USDA had upgraded to a system of mechanized fiber measurement, which provided more precise and reliable measurements desirable to textile manufacturers (Perkins et al. 1984). Thus, in order to take control of the definition of quality and the creation of benchmark cottons, the Chinese state would need to upgrade its domestic quality classification system to rival that of the USDA. To this end, the Chinese state contacted the USDA in 2003 and asked if it would help the Chinese cotton standards agency replicate the U.S. system for the classification of its domestic crop (Laws 2005b). The Chinese state's request was not primarily about technology adoption, as the measurement instrument could be purchased from private companies. What the Chinese state wanted to import and replicate were the USDA's institutional arrangements. To actually use instrument classifications to buy and sell cotton, the measurement instruments must be embedded within institutions that ensure the accuracy and precision of measurement instruments across time and space.

As U.S. industry and USDA representatives explained to me, they agreed to help the Chinese standards agency on the condition that it adopt the USDA benchmark standards, hoping this would reduce the possibility that the Chinese state would introduce rival quality governance. The Chinese state agreed to the deal and in late 2003 announced the launch of the five-year Chinese Cotton Quality Classification Reform Plan (FAS 2004). To this end, officials from the Chinese standards agency, as well as Chinese marketing and agriculture ministry officials, traveled to Memphis in February 2004 to study the U.S. instrument measurement system (Keyes et al. 2005; Laws 2005b). This initial exchange was followed by a number of follow-up visits that involved "intense, detailed information exchanges" (USDA official, as cited in Laws 2005b). With the USDA's help, the CFIB aimed to have a fully functioning mechanized classification system by 2010 .

The Chinese state and textile manufacturers in China further faced the problem of institutional dependence in their effort to challenge transnational merchants' hegemony over dispute settlement. Given their commitments at the WTO, their challenge depended on a successful bid for private authority through private trade associations, which were underdeveloped in China. Historically, the Chinese state had strictly controlled cotton imports and exports through the China National Textiles Import and Export Corporation (Chinatex). However, through its accession agreement to the WTO, the Chinese state was compelled to open up cotton import and export trading to private firms. Chinatex remained a state trading enterprise but had to make room for private firms, and particularly a growing group of private and foreigninvested textile manufacturers, to import cotton.

The Chinese textile sector itself was undergoing a radical transformation in ownership patterns in this period. In 2000 , twenty percent of textile firms were state-owned or statecontrolled (i.e. partially privatized); by 2005 , this fell to just four percent. With a shift from state 
to private ownership came an influx of new textile manufacturers. The number of cotton textile manufacturers tripled, from 2,692 firms in 2000 to 7,632 firms in 2005 and 10,098 in 2007 (Alpermann 2010:164). ${ }^{3}$ Thus, rather than a single state trading enterprise buying on behalf of state-owned textile industries, a vast array of private textile manufacturers and private trading agencies were now in the importing game.

Thus, to rival Western transnational merchants, the Chinese state established a rival trade association, the China Cotton Association (CCA), under the supervision of the Ministry of Civil Affairs. This trade association was ostensibly a private body that would bring together diverse interests in the cotton trade, including cotton farmers, farmers' cooperatives, merchants, and cotton textile industries, and advise the government on policy matters (China Cotton Association 2011). In addition, as a private body, it could negotiate dispute settlement arrangements as an alternative to Western transnational merchants' private arbitration in an environment that saw the state's role as illegitimate (see Fang 2009). While it could not mandate contract terms or use of their arbitral body, the CCA decided to develop a standard contract that would serve as an industry "best practices" model that textile manufacturers in China could use. Given textile manufacturers' significant dependence on transnational merchants, the CCA allowed transnational merchants to negotiate over the standard contract.

Industry players report that negotiations over the CCA's standard contract were contentious. When the CCA released its official version of the contract in May 2006, it was clear it had engaged in some hegemony-building around its new rules by offering Western merchants concessions. The CCA allowed parties to choose either CIETAC or LCA arbitration and to give equal weight to Mandarin and English interpretations of the contract in case of disputes (China Cotton Association 2006). In the dispute over key quality terms, however, the CCA refused to compromise. To protect textile manufacturers' interests, the CCA maintained the requirement that the quality of all cotton entering China must be certified by the state agency, China Inspection and Quarantine (CIQ) and that CIQ certifications were final in contract quality disputes (China Cotton Association 2006). That is, despite merchants' preference for private quality verification, the Chinese state would maintain its authority to verify import quality. Through the construction of the CCA, the Chinese state-led coalition had thus introduced a rival set of rules for dispute settlement, centered in China.

\section{Reconstituting U.S.-led Sectoral Hegemony}

For the U.S. state and Western transnational merchants, the threat that the Chinese-led coalition would successfully challenge their hegemony over the governance of quality was palpable. In this context, both the U.S. state and transnational merchants sought to amass allies in the cotton trade more broadly in order to reconstitute their hegemony. Their goal was to persuade others involved in the transnational cotton trade around the world to support their governance arrangements before the Chinese state and textile manufacturers in China developed the scientific, technological and institutional capacities to launch their own hegemony-building campaign, which would be backed by the coercive power of being the largest cotton market in

\footnotetext{
${ }^{3}$ Alpermann (2010:163) notes that these figures underestimate the number of firms involved in textile production in China. These figures refer only to the "cotton textile industry", or firms that use only cotton as a fiber input in processing. This thus excludes a vast number of textile manufacturers that blend cotton with other fibers such as synthetics, silk, or wool. In effect, the transition from a single state-owned importer/exporter to a vast number of private importers/exporters is likely more significant than these numbers suggest.
} 


\section{Journal of World-Systems Research}

the world. To this end, the USDA and transnational merchants were compelled to reconstruct their existing institutions in order to give concessions both to the Chinese state and to other potential allies and to craft legitimating discourses that would present their institutions as serving the collective interest of the transnational cotton trade.

The USDA thus attempted to provide intellectual leadership, claiming that it operated the only scientifically valid mechanized classification system that could be used transnationally (see Laws 2005a). To demonstrate this, the USDA created a collective good: a new transnational institutional infrastructure into which cotton-producing countries around the globe could be integrated, that could verify the reliability of mechanized classification systems transnationally. At this time, cotton-producing countries were becoming increasingly interested in adopting mechanized classification to meet the demands of textile manufacturers. Indeed, at the International Cotton Advisory Committee (ICAC), an international commodity organization that brought together cotton-producing countries around the world, a number of cotton producing countries had begun to discuss the creation of an international definition of quality and benchmark standards for use with mechanized classification (ICAC 2003). The USDA attempted to co-opt this process to ensure that all mechanized classification systems adopt the USDA definition of quality and benchmark standards. Within the U.S., the USDA had constructed procedures to verify the reliability of its domestic classification labs. Through the ICAC, the USDA reconstructed these procedures to integrate measurement labs around the world. The USDA, in partnership with the Bremen Fibre Institute, designed quarterly round trials in which the USDA would send cotton samples with known values to the measurement labs around the world, who would measure them and send the results back for verification. By 2007, they had secured the participation of 50 classification laboratories globally (CSITC Task Force 2007). In short, by reconfiguring its quality governance institutions on a global scale and integrating other cotton-producing countries, the USDA began to recast the state apparatus by exercising its power through an inter-state organization and to reconstitute the geographic reach of its standards and benchmark cottons, if not the fractions of capital and geographic regions privileged within them.

Adopting a similar tactic, Western transnational merchants also launched a campaign to recreate the hegemony of private dispute settlement within their trade association among textile manufacturers and regional merchants around the world. First, as the LCA was perceived as a biased organization, transnational merchants endeavored to construct its impartiality by changing some of its rules and procedures. For example, the LCA replaced their adversarial arbitration system, which tended to be influenced by whomever could pay the best arbitrator, with a tribunal system that included a neutral chairperson on each arbitral panel who made the final decision in the dispute (LCA 2003:26-27). Second, the LCA offered moral and intellectual leadership by using these rule changes as the basis of a discursive campaign to claim its legitimate leadership over dispute settlement. In 2004 the LCA re-branded itself as the ICA, the International Cotton Association and cast transnational harmonization around its rules as the only way to ensure "ethical" trading practices in the uncertain global economy (LCA 2003; ICA 2004). To promote this message, the ICA launched an educational campaign to familiarize textile manufacturers and merchants, particularly in countries in the global South, with the newly revised ICA rules. In addition to posting its rules in five languages (ICA 2005, 2006), the ICA held interactive workshops and presentations across five continents (ICA 2006, 2007a, 2009).

Finally, the ICA tackled concerns that its authority structure was unrepresentative by diversifying its directorships and its Rules Committee. In addition to its officers and ordinary 
directors, the ICA added a new category of "associate director" who would be "especially appointed to represent the interests and concerns of international members of the ICA and the principal overseas cotton producing and consuming regions" (ICA 2007b). By 2007, the ICA had appointed associate directors to represent a range of cotton and textile associations around the world (ICA 2007b). In perhaps its most significant concession to establish greater representation, the ICA decided to strategically diversify its Rules Committee, giving every trade association that adopted the ICA rules a seat on this key committee that debated rule changes and drafted proposals to be approved by the membership. In sum, the ICA reconstituted its existing institutions, giving concessions and claiming to represent the collective interest in an effort to persuade other trade associations to support its transnational authority over dispute settlement.

These changes did increase support for the ICA's authority over dispute settlement. The ICA membership increased by thirty-four percent from 2010 to early 2012 (ICA 2012d). Perhaps most importantly, numerous Chinese firms joined the ICA in 2011 and 2012 (ICA 2011b,c,d,e,f; $2012 \mathrm{a}, \mathrm{b}, \mathrm{c}, \mathrm{e})$, and a representative from a state-owned firm, the China National Cotton Group Corporation, was appointed as an Associate Director to represent the interests of the Chinese cotton industry (ICA 2011h). This signaled the growing success of the ICA's efforts to diffuse the challenge from China and integrate Chinese firms into the existing institutional arrangement.

\section{The Instability of Reconstituted Hegemony}

These efforts by the USDA and transnational merchants to reconstitute their hegemony would prove unstable. In terms of the first two governance tasks - the definition of quality and the creation of benchmark cottons, the Chinese state did not intend to simply adopt the U.S. system but preferred to create its own institutional arrangements to challenge those dominated by Western actors. By 2007 evidence was growing that the Chinese state was preparing for a bid to control standards, and particularly that it was considering developing its own benchmark standards for a Short Fiber Index (SFI) (CSITC Task Force 2007:4). Not only would this change the definition of quality by introducing a previously excluded measurement, but it would shift the key coordinating function, the production of benchmark standards, to China, at least for this measurement.

This perceived threat created a new challenge for the USDA: it created a divergence of interests within the domestic core of its hegemonic coalition. The USDA was concerned that U.S. cotton producers would face price discounts on the market if new fiber measurements, such as a Short Fiber Index, were added to the classification system. However, U.S. and European transnational merchants were less interested in preserving advantages for U.S. producers and more interested in ensuring that control of the classification system and benchmark standards did not shift to the Chinese state, which could weaken merchants' influence over the system. Thus, in 2007, transnational merchants publicly supported an effort to include a Short Fiber Index, offering to petition the USDA to develop benchmark standards to this end (CSITC Task Force 2007).

This fracturing of its hegemonic coalition compelled the USDA to give material concessions to China and thus reconfigure which class fractions and geographic regions were privileged in its institutions. In 2009 the USDA announced that it had begun a collaborative study with the Chinese standards agency, the China Fiber Inspection Bureau, to develop benchmark standards for a Short Fiber Index (CSITC Task Force 2009:6). In short, the growing 


\section{Journal of World-Systems Research}

pressure from the Chinese state had begun to shift the focus of research to the inclusion of those measurements of most importance to textile manufacturers in China. The new transnational system of quality governance established by the USDA would increasingly have Chinese characteristics.

In addition, the USDA created a set of procedural standards to verify the validity and reliability of benchmark cottons and had them approved through a private standards development organization (ASTM International) to serve as a form of meta-governance, or standards to govern the standards. The USDA developed the procedural standards such that "other bodies (like in China) have the option of developing their own quality infrastructure and calibration [benchmark] cottons without deviating from the USDA quality and result level" (ITMF 2008:5; see ASTM International 2012). These standards did not preclude the Chinese state from introducing new measurement instruments or creating its own benchmark standards - indeed, they facilitated such developments. These standards did, however, demand transparency, as defined by the USDA. If new instruments or standards were introduced, the USDA could use such procedural standards as the basis of a WTO challenge to guard against manipulation in classification and to ensure that the USDA ultimately played a key role as arbiter of what would count as a legitimate standard. In this way, the USDA acknowledged that, if the Chinese state did supplant its sectoral hegemony, the U.S. coalition would at least position itself hierarchically in the institutional environment to demand transparency.

This new threat from China also compelled Western transnational merchants to develop a new form of meta-governance. The ICA worked with the Bremen Fibre Institute to create an international laboratory certification scheme. The ICA would audit classification laboratories around the world using the USDA's reliability standards to ensure standard levels of quality assurance, regardless of whether they were operating on U.S. or Chinese standards and benchmark cottons. The ICA would maintain a list of these qualifying labs that could be used to resolve quality disputes in line with the ICA Bylaws and Rules (ICA 2011a). If a quality classification was challenged, the ICA Bremen classification laboratory would make the final judgment (CSITC Task Force 2008; ICA 2011a). This can thus best be understood as an effort to at once solidify a particular state-capital nexus that ensured the role of private actors, and especially the ICA, in quality dispute settlement and position private authority on neutral ground - that is, able to perform this role regardless of whether the production of benchmark standards remained in the U.S. or shifted to China.

\section{Conclusion}

The case of quality governance in the transnational cotton trade from 2000-2012 offers a lens through which to explore the intersection of two key dynamics in the global economy: the growing governance roles of transnational firms, and intensifying inter-state competition with the decline of U.S. hegemony and the rise of China. In particular, I demonstrate the utility of conceptualizing hegemony-building functions at the sectoral level as a way to map the intersection of these two phenomena. By linking Arrighi's work on periods of crisis and hegemonic struggle with the study of the institutions governing commodity chains, we can chart the destabilization of hegemonic coalitions of states and firms and the state and private institutions that undergird them, as well as the contingent struggles that generate new configurations of power. 
In the cotton trade, intensifying inter-state and inter-firm competition, largely due to the rise of China, has destabilized the hegemonic state and private institutions established by the USDA and transnational merchants. What has ensued is a struggle over which firms and states would successfully provide new institutions that would at once instantiate their interests and provide a collective good to the transnational cotton trade as a whole. The U.S.-led coalition has, to this point, prevailed by successfully reconstituting its leadership in the sector through a process of hegemony-building. Both the USDA and Western transnational merchants in the ICA recast their existing institutions to better facilitate expanded trade, while at the same time giving material concessions and providing moral and intellectual leadership to persuade others to accept their state and private institutions for quality governance.

While reconstituting the U.S.-led coalition's leadership, however, the process of hegemonic struggle in the sector did significantly recast the institutions governing the trade along the six axes discussed above (see Table 1). First, the state apparatus leading the U.S. coalition transformed through these struggles as the USDA shifted from operating largely as a national state agency, albeit in a formal agreement with private trade associations abroad, to wielding its power through an inter-state organization, the ICAC. Similarly, Western transnational merchants recast their governance institutions, transforming what were largely national trade associations attempting to govern transnational trade to an increasingly transnational trade association that integrated new fractions of capital, particularly textile manufacturers.

These competitive dynamics also shifted to a degree the geographical centering of the reconstituted U.S.-led hegemony. The U.S. was compelled to create standards with Chinese characteristics, including new fiber measurements that privileged the preferences of textile manufacturers in China over those of U.S. cotton producers. Western transnational merchants reconstituted the authority structure of their dispute settlement institutions to make them more inclusive and transparent. This strategy of accommodation may reflect a broader strategy being pursued by the U.S. state. In 2005, the U.S. government posted a dedicated standards attaché in Beijing, making it only the fourth embassy with such an official (in addition to Mexico, Brazil and the European Union). Moreover, some prominent U.S. standards organizations, such as the American National Standards Institute, have deepened their interaction both with Chinese standards bodies and with the U.S. Congress and the executive branch (Kennedy 2006). This suggests a deepening of competitive cooperation that, if replicated more broadly, could aid a stable transformation to a new hegemonic order. As Arrighi (2005:69) argues, "U.S. adjustment and accommodation primarily, but not exclusively, to the rising economic power of the East Asian region is an essential condition for a non-catastrophic transition to a new world order."

Moreover, the efforts of Western transnational merchants to create more inclusive institutions by integrating transnationally-oriented firms from around the world into their trade association suggest new modes of transnational class formation. Some scholars have attempted to measure quantitatively the emergence of a transnational capitalist class through the existence of interlocking boards of directors (Carroll 2010; Carroll and Carson 2003; Carroll and Fennema 2002, 2004; Kentor and Jang 2006; Nollert 2005; Staples 2006). While critical, this study suggests that qualitative work focusing on the processes through which transnational class consciousness is constructed can yield new insights. Van Apeldoorn (2003) has done useful work on this topic in the European context but more work is needed to address the new Asian epicenters of global capitalism. 


\section{Journal of World-Systems Research}

Despite the reconstitution of the institutions by the U.S.-led coalition, the evidence demonstrates that this reconstituted sectoral hegemony remains vulnerable, particularly as the threat of rival Chinese governance institutions has not been put to rest. It is here that we see the effects of the intersection of private governance and inter-state competition. Transnational merchants shaped inter-state competition by destabilizing U.S. state governance and compelling the USDA to pursue new strategies. Fearing continued competition from China and loss of merchant support, the USDA constructed a form of meta-governance by establishing procedural standards to govern any rival effort to produce benchmark standards. This lays a new "track," as any future effort by China to impose new benchmark standards would face challenges if it did not adhere to these internationally accepted procedural standards. This speaks to both the opportunities and constraints on the potential rise of Chinese-led sectoral hegemony. On one hand, a Chinese-led coalition is seen as a credible threat, as evidenced by its ability to secure the assistance of the U.S.-led coalition in developing institutional infrastructure to facilitate its power. On the other hand, the Chinese state faces technological and institutional obstacles that must be overcome before it could credibly challenge the USDA and engage in its own hegemony-building campaign in the sector.

Western transnational firms face distinct challenges in their effort to maintain their position in any hegemonic coalition into the future, given the declining ability of the U.S. state to provide the institutional foundations for their expansion and for the operation of private governance. Indeed, inter-state competition over state governance functions shaped the decisionmaking structure of and tasks conducted by private governance institutions. Western transnational firms were compelled to recast their private governance functions as geopolitically neutral and compatible with either U.S. or Chinese sectoral hegemony. This points to new insights regarding our conceptualizations of private governance. Too often private governance has been theorized as separate from - and even replacing - state governance (see Bartley 2005; Seidman 2007), and inter-state competition has been seen as largely facilitating the rise of private governance through regulatory undercutting (Collins 2003). This case demonstrates not only that private and state governance institutions overlap and intertwine (Bartley 2005, 2011; Cutler 2003; Seidman 2007), but also that geopolitical competition over state governance functions significantly shapes the strategies used in the struggle over private governance institutions.

Despite these transformations, several elements of the U.S.-led hegemonic institutions remained rather stable. The Chinese state made only a weak challenge to the prevailing statecapital nexus, which is somewhat surprising given the attention focused on the Chinese state as

pursuing a more state-centered approach. Similarly, the legitimating discourses of scientific validity and liberal/neoliberal economics were largely unchallenged through these struggles. While the Chinese-led coalition framed its efforts as providing "alternatives" for the cotton trade, it did not offer a competing legitimating discourse for this alternative. To the contrary, its efforts were in many ways straight-jacketed by the institutionalization of scientism and neoliberalism within the WTO, which compelled it to seek a scientific approach to standards and to create a private trade association to address dispute settlement.

Overall, although this struggle is ongoing, it appears that a new sectoral hegemonic coalition, which would likely prominently feature both the Chinese state and transnational merchants, remains a plausible trajectory. The possibility that the Chinese state could take control of the definition of quality and the production of benchmark standards is relatively strong, in part because the U.S. has facilitated its expertise and in part because the Chinese state 
enjoys coercive power as the largest cotton buyer. If the Chinese state were to introduce new benchmark standards, cotton-producing countries around the world would be likely to support the standards of their largest buyer rather than their export competitor - the U.S. That said, the leadership of the Chinese state would likely remain under a degree of U.S. oversight, given the internationally-approved procedural standards that the U.S. has created. The Chinese threat to dispute settlement is weaker, largely because Western transnational merchants have achieved some success in integrating Chinese buyers into their existing governance institution and positioning their institution as geopolitically neutral. Moreover, these merchants still largely hold the coercive advantage in terms of market share. This suggests that Western transnational merchants would be likely to maintain a lead role in a Chinese-led sectoral hegemony.

From the perspective of potential transformations of hegemonic coalitions at the level of the global economy as a whole, these findings raise critical comparative questions - that is, are we seeing similar processes occurring in other commodity chains/sectors? While this question is beyond the scope of this article and warrants further research, some comparative observations can be made. The Chinese coalition's ability to compel Western actors to aid its efforts to control standard-setting is not unique to the cotton trade. Indeed, foreign technological and institutional know-how has been an important component in a number of more prominent Chinese standards initiatives. For example, when the Chinese state and Chinese firms began to develop a homegrown third generation ( $3 \mathrm{G}$ ) wireless standard (TD-SCDMA), the German multinational Siemens provided technology that helped Chinese standards development. This standard was ultimately approved in 2000 by the International Telecommunication Union (ITU), the key international standardizing body for information and communications technology (Suttmeier et al. 2006; Zhan 2010; see also Suttmeier and Yao 2004). Similarly, the Chinese coalition's increasing ability to leverage its economic power to reshape sectoral governance is further evident in Richard Appelbaum's work on the apparel industry. Appelbaum (2009:66) argues that Chinese government policies emphasizing indigenous innovation and competitiveness have facilitated the emergence of "giant transnational contractors" in China whose verticallyintegrated supply chains could challenge the power of U.S. and EU-based retailers to govern the apparel commodity chain.

At the same time, however, the ability of the U.S.-led coalition to reconstitute its sectoral hegemony is consistent with findings in other sectors. Both the USDA and Western transnational merchants have sought to give concessions and expand their coalition in order to diffuse the threat from the Chinese coalition. Such efforts to establish a broad, inclusive coalition have proved successful in limiting other standards initiatives in China. For example, China's effort to create national standards for mobile security (WAPI) in 2004 largely failed. In part due to security interests, the coalition in support of WAPI was rather narrow and exclusively Chinabased. Moreover, this narrow coalition faced a large and firmly unified group of U.S. and European multinationals, their Chinese partners, and a range of industry associations in the U.S., the European Union, and Japan that mobilized to challenge it (Kennedy 2006). As Fomin, Su and Gao argue, "a competing standard in the presence of a dominant one is a highly costly and risky endeavor" due to the "switching costs - the interests of consumers, manufacturers and service providers are vested in the installed base of the dominant standard" (2011:749). This suggests that the efforts of the USDA and particularly of transnational merchants to construct a broader global coalition in support of their rule-making authority could be a critical factor into the future. 


\section{Journal of World-Systems Research}

Overall, the study of sectoral hegemonies offers an approach for making sense of broader struggles during periods of crisis and transition. Through struggles over sectoral hegemonies, both state and private institutions governing a commodity chain are transformed, as competitive hegemony-building projects fracture old alliances, generate new power configurations, and begin to shape the contours of new hegemonic coalitions that are constituted by and constitutive of broader hegemonic struggles.

\section{References}

Appelbaum, Richard. 2009. "Big Suppliers in Greater China: A Growing Counterweight to the Power of Giant Retailers." Pp. 65-85 in China and the Transformation of Global Capitalism, edited by H. Hung, Baltimore: The Johns Hopkins University Press.

Arrighi, Giovanni. 1994. The Long Twentieth Century. New York: Verso. . 2005. "Global Governance and Hegemony in the Modern World-System." Pp. 57-71 in Contending Perspectives on Global Governance, edited by A. D. Ba and M. J. Hoffmann. New York: Routledge. 2007. Adam Smith in Beijing: lineages of the twenty-first century. London: Verso.

Arrighi, Giovanni and Beverly Silver. 1999. Chaos and Governance in the Modern WorldSystem. Minneapolis: University of Minnesota. . 2001. "Capitalism and World (Dis)order." Review of International Studies 27:257-279.

ASTM International. 2012. ASTM D7642 - 12 Standard Practice for Establishment of Calibration Cottons for Cotton Classification Instruments. Accessed October 8, 2012. http://www.astm.org/Standards/D7642.htm?

Baffes, John. 2001. "Policy Reform Experience in Cotton Markets." Pp. 165-190 in Commodity Market Reforms: Lessons of Two Decades, edited by T. Akiyama, J. Baffes, D. Larson, and P. Varangis. The International Bank for Reconstruction and Development/The World Bank.

Baffes, John, Ousmane Badiane, and John Nash. 2004. "Cotton: Market Structure, Policies and Development Issues." Paper presented at the WTO Africa Regional Workshop on Cotton, Cotonou, Benin, March 23-24.

Bair, Jennifer. 2005. "Global Capitalism and Commodity Chains: Looking Back, Going Forward." Competition \& Change 9(2):153-180.

Bair, Jennifer and Gary Gereffi. 2001. "Local Clusters in Global Chains: The Causes and Consequences of Export Dynamism in Torreon's Blue Jeans Industry." World Development 29(11):1885-1903.

Bartley, Tim. 2005. "Corporate Accountability and the Privatization of Labor Standards: Struggles Over Codes of Conduct in the Apparel Industry." Research in Political Sociology 14:211-244. . 2007. "Institutional Emergence in an Era of Globalization: The Rise of Transnational Private Regulation of Labor and Environmental Conditions." American Journal of Sociology 113(2):297-351.

. 2011. "Transnational Governance as the Layering of Rules: Intersections of Public and Private Standards." Theoretical Inquiries in Law 12(2):517-542. 
Beeson, Mark. 2013. "Can China Lead?" Third World Quarterly 34(2):233-250.

Cardoso, Fernando H. and Enzo Faletto. 1979. Dependency and Development in Latin America. Translated by Marjory M. Urquidi. Berkeley: University of California Press.

Carpenter, Claudia. 2009. "Cotton Industry Faces 'Huge Challenge,' Chief Says." Bloomberg, October 8. Accessed November 9, 2009.

Carroll, William K. 2010. The Making of a Transnational Capitalist Class: Corporate Power in the $21^{\text {st }}$ Century. London: Zed.

Carroll, William K. and Colin Carson. 2003. "The Network of Global Corporations and Elite

Policy Groups: A Structure for Transnational Capitalist Class Formation?" Global Networks 3(1):29-57.

Carroll, William K. and Meindert Fennema. 2002. "Is There a Transnational Business Community?" International Sociology 17(3):393-419.

2004. "Problems in the Study of the Transnational Business Community." International Sociology 19(3):469-478.

China Cotton Association. 2006. Cotton Purchase Contract: Applicable to Non-Chinese Made Cotton Trade.

. 2011. "China Cotton Association Introduction." Accessed November 3, 2011. http://www.china-cotton.org/english/introduction.php?articleid=18

Chorev, Nitsan and Sarah Babb. 2009. "The Crisis of Neoliberalism and the Future of International Institutions: The IMF and the WTO in Comparative Perspective." Theory and Society 38:459-484.

Chung, Wai-Keung and Gary G. Hamilton. 2001. "Social Logic as Business Logic: Guanxi, Trustworthiness, and the Embeddedness of Chinese Business Practices." Pp. 325-346 in Rules and Networks: The Legal Culture of Global Business Transactions, edited by R. Appelbaum, W. L. F. Felstiner, and V. Gessner. Portland: Hart.

Ciccantell, Paul and David A. Smith. 2009. "Rethinking Global Commodity Chains: Integrating Extraction, Transport and Manufacturing." International Journal of Comparative Sociology 50(June/August):361-384.

Collins, Jane. 2003. Threads: Gender, Labor and Power in the Global Apparel Industry. Chicago: University of Chicago Press.

. 2005. "New Directions in Commodity Chain Analysis of Global Development Processes." Pp. 3-18 in New Directions in the Sociology of Global Development, Research in Rural Sociology and Development, edited by F. H. Buttel and P. D. McMichael. Vol. 11. Amsterdam: Elsevier.

CSITC (Commercial Standardization of Instrument Testing of Cotton) Task Force. 2007. Report of the $8^{\text {th }}$ Meeting of the Task Force on Commercial Standardization of Instrument Testing of Cotton, Izmir, Turkey, October 21. Accessed April 13, 2008. www.icac.org. . 2007. Report of the $8^{\text {th }}$ Meeting of the Task Force on Commercial Standardization of Instrument Testing of Cotton, Izmir, Turkey, October 21. Accessed April 13, 2008. www.icac.org.

. 2008. Report of the $9^{\text {th }}$ Meeting of the Task Force on Commercial Standardization of Instrument Testing of Cotton, Bremen, Germany, April 2. Accessed September 14, 2010. www.icac.org.

. 2009. Report of the 11th Meeting of the Task Force on Commercial Standardization of Instrument Testing of Cotton, Washington, D.C., May 26. Accessed September 14, 2010. www.icac.org. 
Cutler, A. Claire. 2002. "Private International Regimes and Interfirm Cooperation." Pp. 23-40 in The Emergence of Private Authority in Global Governance, edited by R. B. Hall and T. J. Bierstecker. Cambridge: Cambridge University.

2003. Private Power and Global Authority: Transnational Merchant Law in the Global Political Economy. Cambridge: Cambridge University.

Cutler, A. Claire, Virginia Haufler, and Tony Porter. 1999. "The Contours and Significance of Private Authority in International Affairs." Pp. 333-376 in Private Authority and International Affairs, edited by A. C. Cutler, V. Haufler, and T. Porter. Albany: State University of New York.

Dezalay, Yves and Bryant Garth. 1995. "Merchants of Law as Moral Entrepreneurs: Constructing International Justice from the Competition for Transnational Business Disputes." Law \& Society Review 29(1):27-64.

Dicken, Peter. 2003. Global Shift: Reshaping the Global Economic Map in the $21^{\text {st }}$ Century, $4^{\text {th }}$ edition. Thousand Oaks: Sage.

Dolan, Catherine and John Humphrey. 2000. "Governance and Trade in Fresh Vegetables: The Impact of UK Supermarkets on the African Horticulture Industry." Journal of Development Studies 37(2):147-176.

Estur, Gérald. 2004. "U.S. Exports: Is Quality at Issue?" Cotton: Review of the World Situation 57(3, Jan-Feb):13-16.

Fang, Gao. 2009. "Playing a Key Role in the International Cotton Affairs." Cotton Outlook, Special Feature: Cotton Trading Relationships with China, June:8-9. Accessed November 10, 2011. http://www.cotlook.com/new content files/Cotlook ChinaSpFt.pdf

FAS (Foreign Agricultural Service). 2004. Peoples Republic of China, Cotton and Products Annual. United States Department of Agriculture, Foreign Agricultural Service, Global Agriculture Information Network (GAIN) Report Number CH4013, May 1.

Fomin, Vladislav V., Junbin Su, and Ping Gao. 2011. "Indigenous Standard Development in the Presence of Dominant International Standards: The Case of AVS Standard in China." Technology Analysis \& Strategic Management 23(7):745-758.

Gellert, Paul and Jon Shefner. 2009. "People, Place, And Time: How Structural Fieldwork Helps World-Systems Analysis." Journal of World-Systems Research XV(2).

Gereffi, Gary. 1994. "The Organization of Buyer-driven Global Commodity Chains: How U.S. Retailers Shape Overseas Production Networks." Pp. 95-123 in Commodity Chains and Global Capitalism, edited by G. Gereffi and M. Korzeniewicz. Westport, CT: Praeger. . 2001. "Shifting Governance Structures in Global Commodity Chains, with Special Reference to the Internet." American Behavioral Scientist 44(10):1617-1637. 2013. "Global Value Chains in a Post-Washington Consensus World." Review of International Political Economy. DOI: 10.1080/09692290.2012.756414

Gereffi, Gary and Stacey Frederick. 2010. "The Global Apparel Value Chain, Trade, and the Crisis: Challenges and Opportunities for Developing Countries." Pp. 157-208 in Global Value Chains in a Post-Crisis World: A Development Perspective, edited by $\mathrm{O}$. Catteneo, G. Gereffi, and C. Staritz. Washington, D.C.: The World Bank.

Gereffi, Gary, John Humphrey, and Timothy Sturgeon. 2005. "The Governance of Global Value Chains." Review of International Political Economy 12(1):78-104.

Gereffi, Gary and Miguel Korzeniewicz, eds. 1994. Commodity Chains and Global Capitalism. Westport: Praeger.

Gills, Barry K. 2013. "Going South: Capitalist Crisis, Systemic Crisis, Civilizational Crisis." 
Third World Quarterly 31(2):169-184.

Gramsci, Antonio. 1971. Selections from the Prison Notebooks of Antonio Gramsci. New York: International Publishers.

Haufler, Virginia. 2001. A Public Role for the Private Sector: Industry Self-Regulation in a Global Economy. Washington, D.C.: Carnegie Endowment. . 2003. "Globalization and Industry Self-Regulation." Pp. 226-252 in Governance in a Global Economy: Political Authority in Transition, edited by M. Kahler and D. A. Lake. Princeton: Princeton University Press.

Henderson, Jeffrey, Peter Dicken, Martin Hess, Neil Coe, and Henry Wai-Chung Yeung. 2002. "Global Production Networks and the Analysis of Economic Development." Review of International Political Economy 9(3):436-464.

Hopkins, Terrence K. and Immanuel Wallerstein. 1977. "Patterns of Development of the Modern World-System." Review 1(2):11-145. . 1986. "Commodity Chains in the World-Economy Prior to 1800." Review 10(1):157170.

Hung, Ho-fung. 2009. "Introduction: The Three Transformations of Global Capitalism." Pp. 1-21 in China and the Transformation of Global Capitalism, edited by H. Hung. Baltimore: Johns Hopkins University Press.

ICA (International Cotton Association Limited). 2004. Annual Report and Accounts 2004. Liverpool: The International Cotton Association. Accessed June 18, 2007. www.icaltd.org/.

. 2005. Annual Report and Accounts 2005. Liverpool: The International Cotton Association. Accessed June 18, 2007. www.ica-1td.org.

. 2006. Annual Report and Accounts 2006. Liverpool: The International Cotton Association. Accessed March 22, 2009. www.ica-ltd.org . 2007a. ICA Members Newsletter, issue 16. Accessed 06-18-07 at: www.ica-ltd.org. 2007b. The International Cotton Association Limited. Accessed March 22, 2009. www.ica-1td.org.

2009. Membership Directory 2009, Incorporating Annual Review 2008. Liverpool, International Cotton Association Limited. Accessed December 15, 2009. http://www.icaltd.org.

. 2011a. 2012 will see the launch of the ICA Bremen International Laboratory Certification scheme. International Cotton Association. Accessed December 10, 2011. http://www.ica-ltd.org/our-services/ica-bremen-testing-and-research/internationallaboratory-certification-scheme.

. 2011b. Another good month for members. ICA Newsreel, September 8. 2011c. Bumper month for new members. ICA Newsreel, August 11. 2011d. Meet more members. ICA Newsreel, July 14. . 2011e. Meet the members. ICA Newsreel, May 12. . 2011f. Meet the members. ICA Newsreel, June 9. . $201 \mathrm{lg}$. New centre of excellence is officially launched. ICA News Round-up. Accessed December 10, 2011. http://www.ica-ltd.org/blog/new-centre-of-excellence-is-officiallylaunched. . 2011h. New ICA President and Board Elected. Press release, November 3. Accessed December 10, 2011. http://www.ica-ltd.org/blog/new-ica-president-and-board-elected. . 2012a. Four more members. ICA Newsreel, February 14. 
.2012b. Membership update. ICA Newsreel, May 10.

. 2012c. Member update. ICA Newsreel, January 12.

2012d. Record number of arbitrations. ICA Newsreel, January 12. Available: http:/www.ica-ltd.org/blog/record-number-of-arbitrations.

.2012e. Seven sign up. ICA Newsreel, April 17.

ICAC (International Cotton Advisory Committee. 2003. Statement of the $62^{\text {nd }}$ Plenary Meeting: The World of Cotton: Developments and Remedies. Proceedings of the $62^{\text {nd }}$ Plenary Meeting of the International Cotton Advisory Committee, Gdañsk, Poland, September 712. Accessed April 3, 2007.

http://www.icac.org/meetings/plenary/62gdansk/documents/english/e plenary statement. $\underline{\mathrm{pdf}}$

ICAC (International Cotton Advisory Committee). 2008. Cotton: World Statistics. Bulletin of the International Cotton Advisory Committee, Washington, D.C. May Update.

ITMF (International Textile Manufacturers' Federation). 2008. International Committee on Cotton Testing Methods Progress Report. Proceedings of the ICCTM Meeting in Bremen, April 1-2. Accessed November 10, 2011.

http://www.itmf.org/cms/media/reports/Proceedings2008-GeneralReport-Website.pdf.

Jaffee, Dan. 2007. Brewing Justice. Berkeley: University of California.

Kennedy, Scott. 2006. "The Political Economy of Standards Coalitions: Explaining China's Involvement in High-Tech Standards Wars." Asia Policy 2(July):41-62.

Kentor, Jeffrey and Yong Suk Jang. 2004. "Yes, There is a (Growing) Transnational Business Community." International Sociology 19(3):355-368.

Keyes, Norma, James Knowlton, and Brenda Patterson. 2005. "ASTM Cotton Fiber Standards." ASTM Standardization News, September. Accessed October 9, 2008. http://www.astm.org/SNEWS/SEPTEMBER 2005/kkp sep05.html.

Laws, Forrest. 2005a. "Debating Universal Cotton Standards." Delta Farm Press, July 6. Accessed September 1, 2010. http://deltafarmpress.com/debating-universal-cottonstandards.

. 2005b. "USDA Helps China Develop Cotton Classing System." Western Farm Press, July 2. Accessed September 1, 2010. http://westernfarmpress.com/usda-helps-chinadevelop-cotton-classing-system.

LCA (Liverpool Cotton Association). 2003. Annual Report and Accounts 2003. Liverpool: The Liverpool Cotton Association. Accessed June 18. 2007. www.ica-ltd.org.

McMichael, Philip. 2004. Development and Social Change: A Global Perspective, $3^{\text {rd }}$ Edition. Thousand Oaks: Pine Forge.

Moore, Jason. 2010. "Amsterdam is Standing on Norway', Part I: The Alchemy of Capital, Empire, and Nature in the Diaspora of Silver, 1545-1648." Journal of Agrarian Change 10(1):33-68.

Nollert, Michael. 2005. "Transnational Corporate Ties: A Synopsis of Theories and Empirical Findings." Journal of World-Systems Research 11(2):289-314.

Overbeek, Henk. 2005. "Global Governance, Class, Hegemony: A Historical Materialist Perspective." Pp. 39-56 in Contending Perspectives on Global, edited by A. D. Ba and M. J. Hoffmann. New York: Routledge.

Perkins, Henry, Don E. Ethridge, and Charles K. Bragg. 1984. "Fiber." Pp. 437-509 in Cotton, edited by R. J. Kohel and C. F. Lewis. Madison: American Society of Agronomy. 
Pieterse, Jan Nederveen. 2011. "Global Rebalancing: Crisis and the East-South Turn." Development and Change 42(1):22-48.

Quark, Amy A. 2008. "Toward a New Theory of Change: Socio-Natural Regimes and the Historical Development of the Cotton Textiles Commodity Chain." Review: $A$ Journal of the Fernand Braudel Center, XXXI(1).

2013. Global Rivalries: Standards Wars and the Transnational Cotton Trade. Chicago: University of Chicago.

Raikes, Phillip, Michael F. Jensen, and Stefano Ponte. 2000. "Global Commodity Chain Analysis and the French Filière Approach: Comparison and Critique." Economy and Society 29(3):390-417.

Review. 2000. Special Issue on Commodity Chains in the World-Economy, 1590-1790 XXIII(1).

Review of International Political Economy. 2013. Special issue, "Dreaming with the BRICS: The Washington Consensus and the New Political Economy of Development," 20(2).

Rosen, Ellen I. 2002. Making Sweatshops: The Globalization of the U.S. Apparel Industry. Berkeley: University of California Press.

Seidman, Gay. 2007. Beyond the Boycott: Labor Rights, Human Rights, and Transnational Activism. New York: Russell Sage Foundation.

Smith, David A. 1993. "Technology and the Modern World-System: Some Reflections." Science, Technology \& Human Values 18(2):186-195.

Staples, Clifford L. 2006. "Board Interlocks and the Study of the Transnational Capitalist Class." Journal of World-Systems Research XII(2):309-319.

Steinfeld, Edward S. 2010. Playing our Game: Why China's Economic Rise Doesn't Threaten the West. Oxford: Oxford University Press.

Suttmeier, Richard and Xiangkui Yao. 2004. "China's Post-WTO Technology Policy: Standards, Software and the Changing Nature of Techno-Nationalism." NBR Special Report, No. 7, May.

Suttmeier, Richard P., Xiangkui Yao, and Alex Zixiang Tan. 2006. "Standards of Power? Technology, Institutions, and Politics in the Development of China's National Standards Strategy." NBR Special Report, No. 10. June.

Talbot, John M. 2004. Grounds for Agreement: The Political Economy of the Coffee Commodity Chain. New York: Rowman and Littlefield.

Tenny, Lloyd S. 1925. "Universal Cotton Standards." The American Review of Reviews LXXII(August):184-188.

Third World Quarterly. 2013a. Special Issue: "Foreign Policy Strategies of Emerging Powers in a Multipolar World," 34(6).

.2013b. Special issue on "Rising Powers and the Future of Global Governance," 34(2).

Tomich, Dale. 1990. Slavery in the Circuit of Sugar: Martinique and the World Economy, 1830 1848. Baltimore: Johns Hopkins University.

USDA (United States Department of Agriculture). 1924. The United States Cotton Standards Act and the Universal Standards: Essential Provisions of the United States Cotton Standards Act. Bureau of Agricultural Economics, Service and Regulatory Announcements No. 82, March.

. 2011. Cotton and Wool Yearbook. Economic Research Service. At: http://usda.mannlib.cornell.edu/MannUsda/viewDocumentInfo.do?documentID=1282

Vanaik, Achin. 2013. "Capitalist Globalization and the Problem of Stability: Enter the New Quintent and Other Emerging Powers." Third World Quarterly 34(2):194-213. 
van Apeldoorn, Bastiaan, Naná de Graaff, and Henk Overbeek. 2012. "The Reconfiguration of the Global State-Capital Nexus." Globalizations 9(4):471-486.

Wallerstein, Immanuel. 1984. The Politics of the World-economy: The States, the Movements and the Civilizations. Cambridge: Cambridge University Press. . 2000. "Introduction to Special Issue on Commodity Chains in the World Economy, 1590 to $1790 . "$ Review 23(1):1-14.

WTO (World Trade Organization). 2002. Notification by the People's Republic of China to the Committee on Technical Barriers to Trade. G/TBT/N/CHN/7, August 9.

Zhan, Ailan. 2010. "Standardisation and Innovation in China: TD-SCDMA Standard as a Case." International Journal of Technology Management 51(2/3/4):453-468. 